\title{
POLISI SANTRI DALAM ORGANISASI KEPOLISIAN RESOR KOTA PALOPO
}

\author{
Oleh : Ilham Laman \\ Ilham.laman@uin-alauddin.ac.id \\ Fakultas Syari'ah dan Hukum UIN Alauddin Makassar
}

\begin{abstract}
The police are one government agency established to maintain security and public order, as well as provide security and peace for the community. This role is carried out based on Law number 2 of 2002. This role is then leading to defining the vision and mission of the police as an institution to protect, guide, and serve the public, as well as to enforce the law. Accordingly, the police strive to create innovations for society by applying several programs to maintain their duties. For instance, both the city police of Palopo and the regional police of Sulawesi Selatan initiate a program called "Polisi Santri" referring to the group of police officers who have adequate Islamic knowledge in the institution. This program aims to make people feel secure and to enhance their spiritual knowledge. Besides, it also becomes an alternative for the criminals who will be guided based on Islamic teachings and approaches to prevent them for doing the same mistakes, to create a safe environment, and to prevent any disturbances in the community.
\end{abstract}

Keyword: Police; Santri; Protection; Security Guarantee; Islamic teachings

\section{Abstrak}

Kepolisian merupakan salah satu instansi pemerintah yang dibentuk untuk menjaga keamanan dan ketertiban umum, serta memberikan keamanan dan ketentraman bagi masyarakat. Peran tersebut dilakukan berdasarkan Undang-Undang Nomor 2 Tahun 2002. Peran tersebut kemudian mengarah pada penetapan visi dan misi polisi sebagai lembaga pengayom, pengayom, dan pengabdian masyarakat, serta penegakan hukum. Sejalan dengan itu, Polri berupaya menciptakan inovasi bagi masyarakat dengan menerapkan berbagai program dalam menjalankan tugasnya. Misalnya, baik Polda Palopo maupun Polda Sulawesi Selatan menggagas program "Polisi Santri" yang merujuk pada kelompok aparat kepolisian yang memiliki pengetahuan Islam yang memadai di lembaga tersebut. Program ini bertujuan untuk membuat orang merasa aman dan meningkatkan pengetahuan spiritual mereka. Selain itu juga menjadi alternatif bagi para pelaku kejahatan yang akan dibimbing berdasarkan ajaran dan pendekatan Islam untuk mencegah mereka melakukan kesalahan yang sama, menciptakan lingkungan yang aman, dan mencegah terjadinya gangguan di masyarakat.

Kata Kunci: Polisi; Santri; Pengayoman; Jaminan Keamanan; Ajaran Islam 


\section{A. PENDAHULUAN}

Negara merupakan tempat berkumpul dalam skala yang besar, secara terminologis negara diartikan sebagai organisasi tertinggi diantara suatu kelompok masyarkat yang mempunyai cita-cita untuk bersatu, hidup dalam kawasan dan mempunyai pemerintah yang berdaulat. ${ }^{1}$ Salah satu hak yang menjadi perioritas negara kepada setiap warga negara adalah rasa aman. Oleh sebab itu, setiap negara memiliki cara dalam memberikan rasa aman pada setiap warga negaranya. Karena tanpa rasa aman maka setiap warga negara tidak akan merasa tenang dalam melaksanakan setiap aktifitasnya sehari-hari, bahkan dengan jaminan rasa aman inilah yang akan menjadikan warga negara menjadi produktif untuk memajukan negaranya.

Jaminan rasa aman inilah yang kemudian menjadikan beberapa negara menyiapkan alat negara pada bidang tersebut, untuk menfasilitasi negara dan rakyat dari bahaya yang ditimbulkan dengan adanya gangguan-gangguan dari dalam atau dari diri warga negaranya serta dari luar negara, baik dilakukan melalui penegakan hukum maupun melaui usaha pencegahan. Alat tersebut kemudian dibuat sebagai bagian dari aparatur negara, yang mendapatkan pelatihan dan pendidikan serta upah dari negara dengan tujuan untuk menjadi bagian dari alat untuk menjamin adanya peyelenggaraan negara.

Salah satu alat kelengkapan negara yang ada di Indonesia untuk mewujudkan cita-cita Indonesia sesuai yang terdapat dalam pondasi Indonesia yaitu undang-undang dasar 1945, undang-undang tersebut menjadi landasan untuk memberikan perlindungan kepada bangsa Indonesia beserta seluruh warga negara Indonesia, untuk memajukan kesejahteraan warga negaranya, mencerdaskan kehidupan bangsa dan ikut melaksanakan ketertiban dunia yang sesuai dengan kemerdekaan, perdamaian abadi dan keadilan dalam kehidupan bermasyarakat; yaitu di hadirkannya Kepolisian Republik Indonesia, sebagai bagian dari pertahanan keamanan negara republik Indonesia yang merupakan bagian yang tak terpisahkan dari ketahanan nasional. ${ }^{2}$ Landasan hukum sebagai penuntun jalannya kepolisian memberikan arahan bahwa lembaga kepolisian di Indonesia bukan hanya berperan sebagai bagian dari penegakan hukum semata. akan tetapi instansi tersebut juga memiliki tujuan dasar, yaitu berperan juga sebagai lembaga penjaga keamanan dan ketertiban masyarakat, serta pelindung, pengayom dan pelayan masyarakat. ${ }^{3}$

${ }^{1}$ Munir Umi Salamah, Suratman, Pendidikan Kewarganegaraan Untuk Perguruan Tinggi, by Anggota IKAPI, Pertama (Malang: Madani, 2017). h. 33

${ }^{2}$ Redaksi Sinar Grafika, Undang Undang Nomor 20 Tahun 1982 Tentang Ketentuan-Ketentuan Pokok Pertahanan Keamanan Negara Republik Indonesia, ed. by PT Karya Unipress, (Jakarta: Sinar Grafika, 1995).

${ }^{3}$ Wahid, 'Peranan Polri Dalam Penegak Keadilan Masyarakat Dalam Perspektif', 8.1 (2015), h. 3. 
Tugas yang di amanahkan oleh negara melalui amanat undang-undang tersebut untuk menjaga keutuhan negara maka Kepolisian di Indonesian melakukan upaya yang telah diprogramkan oleh negara yaitu meningkatkan transparansi dan akuntabilitas para anggota Kepolisian Republik Indonesia dalam menjalankan tugas dan tanggung jawabnya, melakukan penanganan terhadap sasaran yang menjadi titik perioritas yang meliputi: kasus Terorisme, kasus korupsi, kasus ilegal loging, pengedaran dan pemakaian narkoba, ilegal mining, adanya konflik horisontal, perdagangan ilegal Bahan bakar minyak, pengadaan atau pengadaan senjata api dan handak, perjudian, premanisme, penyelundupan, pengamanan pemilihan umum, pengamanan pemilihan kepala daerah, dan melakukan penanganan terhadap aliran sesat. ${ }^{4}$ kepolisian ini kemudian dibentuk pada setiap wilayah baik di tingkat pusat. Provinsi, maupun kota ataupun pedesaan tujuannya untuk memberikan peran maksimal kepada masyarakat. Untuk tingkat kota di bentuklah polisi resort atau di singkat POLRES.

Kota palopo merupakan salah satu kota yang berada di Sulawesi selatan Indonesia ini, juga memiliki satu instansi Kepolisian Resor yang bertujuan untuk memberikan pelayan prima terhadap segala kebutuhan masyarakat sesuai dengan tugas dan fungsi kepolisian, akan tetapi seiring berjalan di Polres tersebut di bentuk pula Polisi Santri yang beranggotakan beberapa personil dari Kepolisian setempat. Pembentukan Polisi santri ini, menimbulkan beberapa pertanyaan mengenai keberadaan serta perannya dalam lingkup Kepolisian Resor Palopo. Seperti yang di ketahui bahwa secara jelas aturan tentang Kepolisian telah di atur dalam undang-undang serta peraturan pemerintah tentang Kepolisian.

\section{METODE}

\section{Jenis Penelitian}

Jenis penelitian yang di gunakan adalah kualitatif dengan desain deskriptif. Adapun cara dalam pengambilan data penelitian ini dengan cara turun langsung ke lapangan. Proses yang dilakukan adalah dengan cara berinteraksi langsung dengan masyrakat serta lokasi yang tempat penelitian untuk mengetahui keberadaan dan peran dari polisi santri di kepolisian polres Palopo.

\section{Lokasi Penelitian}

Lokasi yang menjadi tempat melaksanakan penelitian ini yaitu di Polres Palopo. Polres yang ada di kota Palopo ini merupakan salah satu kota yang ada di sulawesi selatan yang memiliki Polisi santri.

${ }^{4}$ Wahid, h. 8 


\section{Sumber Data}

Penelitian ini memiliki suber data yang di sesuaikan dengan jenis atau gambaran penelitian yang digunakan yaitu studi lapangan, maka hasilnya diperoleh dari hasil observasi dan wawancara, dengan sumber data primer yang di peroleh dengan cara wawancara langsung kepada informan yaitu Kapolres dan beberapa rekan Polisi Polres Palopo yang menjadi Polisi Santri dan data sekunder yang diperoleh dengan mengumpulkan data melalui kepustakaan.

\section{Teknik Pengumpulan Data}

Pengumpulan data pada penelitian ini, penulis sesuaikan dengan metode atau jenis penelitian kualitatif. Cara atau teknik pengumpulan data ini dilakukan dengan melaksakan kunjungan langsung ke tempat penelitian untuk mendapatkan keterangan yang akurat, cara ini di lakukan untuk menghindari adanya kesalahan serta kekliruan dalam menyajikan informasi. Adapun teknik dalam pengumpulan data ini yaitu dimulai dengan proses observasi. Adapun metode obeservasi yang merupakan kegiatan sehari-hari manusia melalui penggunaan panca inderanya seperti; mata sebagai alat bantu utama selain dari panca indera lainnya seperti telinga, penciuman, mulut dan kulit. ${ }^{5}$ Kemudian yang menjadi pokok pencarian informasi penulis menggunakan cara wawancara. Wawancara merupakan suatu metode atau cara memperoleh keterangan yang butuhkan dalam penulisan sebuah karya tulis ilmiah dengan cara melakukan tanya jawab dengan informan yang menjadi sasaran pengambilan informasi. Hal ini di lakukan dengan berhadapan langsung antara peneliti atau pewawancara dengan informan atau informan yang di wawancarai, hal ini di laksanakan dengan atau tanpa adanya pedoman atau rubrik wawancara, dimana antara yang mewawancarai dengan informan melakukan interaksi sosial yang sudah cukup lama. ${ }^{6}$ Untuk memperoleh informasi tentang pokok permasalahan. Sebagai pelengkap maka penulis menggunakan cara dokumentasi. Penggunaan dokumentasi merupakan cara pengumpulan data-data dan bahan-bahan seperti dokumen, ${ }^{7}$

${ }^{5}$ Burhan Buangin, Penelitian Kualitatif, ed. by Katalog dalam Terbitan, Pertama Cet. 2 (Jakarta: Kencana Pranada Media Group, 2008). h. 115

${ }^{6}$ Burhan Buangin. h. 108 2010), h. 28.

7 Soerjono Soekanto, Pengantar Penelitian Hukum, Cet. 3 (Jakarta: PT Universitas Indonesia, 
seperti foto, buku, majalah, surat kabar, Jurnal, undang-undang.

\section{Analisis Data}

Untuk menyederhanakan informasi atau data penelitian maka di butuhkan tenknik dalam menganalisis data penelitian yang telah diperoleh. Dalam penelitian ini penulis penulis mengolah data penelitian dengan cara; reduksi data, penyajian datan dan selanjutnya Verifikasi data.

\section{RESHULTS \& DISCATION}

\section{Polisi}

Asal kata Polisi berasal dari kata Politea atau negara kota, kata atau istilah ini lahir pada zaman yunani kuno dimana manusia hidup pada zaman tersebut secara berkelompok, kelompok manusia inilah kemudian membuat suatu himpunan, sehingga dari himpunan itulah yang disimpulkan dengan arti kota (Polis). Untuk membentuk kehidupan masyarkat di kota agar dapat tertata dengan baik, maka dibuatlah norma. Norma yang ada tersebut di tegakkan melalui suatu kekuatan, kekuatan yang di bentuk inilah yang kemudian dinamakan kepolisian. ${ }^{8}$ Adapun menurut Black's Law Dictionary Police is the function of that baranch of the adminstrative machinery of goverment which is charged with the preservatin of public health, safety, and morals, and prevention, detection, and punisment of crimes. ${ }^{9}$ Selain definisi tersebut Latour Bruno membagi dalam dua definisi Polisi antara lain;

Pertama bahwa polisi diartikan secara formal, dalam arti ini polisi mencakup penjelasan tentang organisasi dan kedudukan suatu instansi kepolisian Negara republik Indonesia, sedang dalam arti kedua polisi dimaknai secara materil, dalam arti ini polisi mencakup tentang jawabanjawaban terhadap berbagai persoalan, tugas serta wewenang kepolisian dalam rangka menghadapi bahaya atau gangguan keamanan serta ketertiban, baik dalam rangka kewenangan kepolisian umum melalui ketentuan-ketentuan yang diatur dalam peraturan perundang-undangan. ${ }^{10}$

Definisi di atas memberikan gambaran akan arti serta fungsi polisi sebagai bagian dari pertahanan Negara, sedang dalam kamus bahasa Indonesia

8 Viswandro dan bayu Saputra Maria Matilda, Mengenal Profesi Penegak Hukum, Buku Rujukan Berkarier Di Bidang Hukum, Edisi Pert (Jakarta Seatan: Pusaka Yustisia, 2015), h. 7

${ }^{9}$ Henry Campbell Black, 'Black' S Law Dictionary', West Publisihing Co, 1999, 1956.

10 Latour Bruno, 'Analisis Yuridis Forum Kemitraan Polisi Dan Masyarakat Dalam Penyelesaian Masalah Melalui Musyawarah Berdasarkan Skep Kapolri No. : Skep/737/X/2005 Tentang Kebijakan Dan Strategi Kepolisian', Journal of Chemical Information and Modeling, 53.9 (2019), 1689-99 <https://doi.org/10.1017/CBO9781107415324.004>. 
menjelaskan bahwa Kepolisaian artinya sesuatu yang bertalian dengan Polisi. ${ }^{11}$ Sementara itu, Undang-undang Republik Indonesia Nomor 2 tahun 2002 yang mengatur tentang Kepolisian Negara Republik Indonesia, dalam pasal satu poin pertama memberikan penjelasan bahwa; Kepolisian merupakan berbagai hal yang berkaitan dengan fungsi lembaga Polisi sesuai yang diatur oleh peraturan perundang-undangan. ${ }^{12}$

Pendefinisian ini menunjukkan bahwa istilah Kepolisian yang dimaksud disini adalah segala hal yang memiliki hubungan dengan institusi Polisi, baik yang berbungan dengan tugas ataupun fungsi dari Polisi, maupun mengenai para personil polisi maupun lembaganya. Kepolisian adalah salah satu institusi negara yang memiliki peran yang penting disetiap negara. Aturan perundangundangan yang membahas tentang aturan mengenai kepolisian pada pasal pertama menjelaskan bahwa Kepolisian senantiasa mengembang fungsi pemerintahan negara dibidang pemeliharaan keamanan serta ketertiban masyarakat, selain itu, polisi juga merupakan pondasi penegakan hukum menjadi pelindung perlindugan, pengayoman, dan pelayan masyarakat. ${ }^{13}$

Lembaga Kepolisian di Indonesia diatur oleh aturan perundangundangan UU Nomor dua Tahun 2002 tentang Kepolisian Negara Republik Indonesia, yang memiliki peran sebagai alat penegak hukum yang memiliki tugas utama memelihara keamanan dalam negeri, dalam menjalankan tugas sebagai penegak hukum, setiap personil Polisi selalu mengutamakan hak asasi setiap warga dan hukum negara. Polisi diberikan tanggung jawab lebih dalam melaksanakan tugasnya secara adil dan bijaksana, serta mendatangkan rasa aman dan tentram. Instansi Kepolisian di Indonesia merupakan alat negara yang memiliki peran pemelihara keamanan dan ketertiban bagi masyarakat, menjadi penegak hukum, serta menjadi alat yang memiliki fungsipelindung, sebagai pengayoman, dan melaksanakan peran pelayanan masyarakat, hal tersebut sesuai dengan Visi Kepolisian Republik Indonesia yaitu;

Polri yang mampu menjadi pelindung, pengayom, dan pelayan masyarakat, yang selalu dekat dan bersama-sama dengan masyarakat, serta menjadi penegak hukum yang memiliki nilai profesional serta proporsional, yang senantiasa menjunjung tinggi supremasi hukum dan hak asasi manusia, pemeliharaan keamanan, dan ketertiban serta mewujudkan keamanan dalam negeri dalam suatu kehidupan nasional yang demokratis dan masyarakat yang sejahtera. $^{14}$ 2008), h. 64

11 Tim Redaksi Kamus Bahasa Indonesia, Kamus Bahasa Indonesia, Kedua (Jakarta Pusat,

12 Undang -undang Kepolisian Negara Republik Indonesia Nomor 2 Tahun 2002, Undang Undang Kepolisian Negara Republik Indonesia, ed. by Sinar grafika Offset, Cetakan ke (Jakarta: Sinar Grafika, 2009), h. 3

${ }^{13}$ Undang -undang Kepolisian Negara Republik Indonesia Nomor 2 Tahun 2002, h. 4

14 Kelik Pramudya dan Ananto Widiatmoko, Pedoman Etika Profesi Aparat Hukum (Yogyakarta, 2010), h. 54 
Oleh karena itu, polisi yang merupakan alat negara memiliki kewajiban untuk menghormati, melindungi, dan menegakkan hak asasi manusia setiap warga negara dalam menjalankan tugas serta fungsinya.

Melalui visi Kepolisian tersebut, maka dalam pelaksananaanya, di lakukan penjabaran melalui misi kepolisian Indonesia, diantaranya;

1. Memberikan perlindungan, pengayoman dan pelayanan kepada masyarakat (meliputi aspek Security, surety, safety, dan peace)

2. Memberikan bimbingan kepada masyarakat melalui upaya preemtif dan preventif yang dapat meningkatkan kesadaran dan kekuatan serta kepatuhan hukum masyarakat (law abiding citizenship)

3. Memegakkan hukum secara profesional dan proporsional dengan menjunjung tinggi supremasi hukum dan hak asasi manusia menuju kepada adanya kepastian hukum dan rasa keadilan;

4. Memelihara keamanan dan kertiban masyarakat dengan tetap memperhatikan norma norma dan nilai-nilai yang beralaku dalam bingkai integritas wilayah hukum negara kesatuan republik Indonesia;

5. Mengelola sumber daya manuasia Polri secara profesional dalam mencapai tujuan Polri yaitu terwujudnya keamanandalam negeri sehingga dapat mendorong terjadinya gairah kerja guna mencapai kesejahteraan masyarakat;

6. Meningkatkan upaya konsilidasi kedala (internal Polri) sebagai upaya menyamakan Visi dan misi Polri kedepan;

7. Memelihara solidaritas institusi Polri dari berbagai pengaruh eksternal yang sangat merugikan organisasi.

8. Melanjjutkan operasi pemulihan keamanan di beberapa wilayah konflik guna menjamin keutuhan negara kesatuan republik Indonesia;

9. Meningkatkan kesadaran hukum dan kesadaran berbangsa dari masyarakat yang ber-bhineka tunggal ika. ${ }^{15}$

Berdasarkan pada uraian tentang visi dan misi tersebut, maka dalam perekrekutan Polri di berikan syarat yang tidak mudah, demi mendapatkan sumber daya manusia yang mumpuni dalam melaksanakan tugas dan fungsinya sebagai bagian dari alat kelengkapan negara. Melalui undangundang di jelaskan bahwa setiap instansi dari kepolisian dipimpin oleh Kepala kepolisian atau di singkat Kapolri yang tanggung jawab kepada Presiden dalam melaksanakan setiap tugas maupun tanggung jawab yang telah di amahkan. Pengangkatan maupun pemberhentian Kapolri menjadi kewenangan dari Presiden melalui persetujuan dari DPR (Dewan Perwakilan Rakyat). Sebagai bagaian dari salah satu alat negara yang berperan dalam memelihara keamanan, menjaga ketertiban masyarakat, melakukan penegakkan hukum, serta menjadi perlindungan, selanjunya menjadi pengayom, serta senantiasa memmberikan pelayanan kepada masyarakat, agar tercipta keamanan di dalam

${ }^{15}$ Maria Matilda. 
negara. Dalam melaksanakan peran ini, pada jabatan penyidik dan penyidik pembantu, serta jabatan fungsional lainnya yang ditetapkan dengan Keputusan Kapolri. ${ }^{16}$

\section{Tujuan dan Fungsi Kepolisian}

Berbicara tentang fungsi ataupun tujuan dari sebuah organisasi, maka kita berfokus pada mengapa organisasi tersebut dibentuk oleh Negara. Menurut buku dari Viswanrdro, bayu dan matilda mengatakan bahwa fungsi Kepolisian adalah bagian dari fungsi pemerintahan negara yang bergerak dibidang pemeliharaan keamanan, penjagaan ketertiban masyarakat, menjadi penegakan hukum, perlindungan masyrakat, pengayoman, serta memberikan pelayanan yang baik terhdap masyarakat. ${ }^{17}$ Sedangkan menurut Satjipto Raharjo dalam bukunya yang berjudul Penegakan Hukum suatu tinjauan sosiologis memberikan penjelasan tentang Fungsi dari kepolisian tersebut sesuai dengan amanat undang-undang mengenai kepolisian, dimana posisi Polisi pada hakikatnya di pandang sebagai hukum yang hidup, karena melalui tangan polisilah hukum mengalami perwujudan atau wujud nyata, setidaknya hal itu, dapat di lihat pada bidang hukum pidana. Seperti yang setiap warga negara ketahui bahwa hukum memiliki tujuan dalam menciptakan ketertiban didalam masyarakat, artinya hukum di gunakan untuk melawan kejahatan. Pada tahap akhir Polisilah yang menentukan secara kongkrit apa yang dimaksud dengan penegakan ketertiban. ${ }^{18}$ Tujuan hukum tersebut sejalan dengan adanya aturan hukum tentang pembentukan polisi dalam undangundang maupun aturan pemerintah tentang kepolisian.

Adapun yang menjadi tujuan dibentuknya lembaga Kepolisian negara di Indonesia untuk mewujudkan negara yang aman yang meliputi terpeliharanya keamanan maupun ketertiban masyarakat, mengusahakan ketertiban serta mengusahakan tegaknya hukum, menyelenggarakan perlindungan warga negara, pengayoman terhadap masyarakat, dan melaksakan pelayanan kepada masyarakat, serta terbinanya suasana ketentraman dalam masyarakat dengan menjunjung tinggi hak asasi manusia. ${ }^{19}$ Melalui amat pada pasal empat dalam undang -undang nomor 2 tentang Kepolisian tersebut, menjadikan Polisi memiliki ruang yang sangat dibutuhkan masyarakat untuk mendapat ketentraman bermasyarakat.

Polisi merupakan salah satu kerangka hukum yang hidup. Janji dan tujuan hukum adalah untuk mengamankan serta melindungi masyarakat

16 Undang -undang Kepolisian Negara Republik Indonesia Nomor 2 Tahun 2002.h. 7-8

17 Viswandro dan bayu Saputra Maria Matilda, Mengenal Profesi Penegak Hukum, Buku Rujukan Berkarier Di Bidang Hukum, Edisi Pert (Jakarta Seatan: Pusaka yustisia, 2015). h. 20

18 Satjipto Raharjo, Penegakan Hukum Suatu Tinjaun Sosiologis, ed. by genta, Edisi 1 (Yogyakarta: genta publising, 2011).

${ }_{19}$ Undang -undang Kepolisian Negara Republik Indonesia Nomor 2 Tahun 2002. 
menjadi sebuh kenyataan tatkala polisi ambil andil di dalamnya. ${ }^{20}$ Secara terperinci tugas dari kepolisian di Indonesia sebagai bukti realisasi dari setiap janji polisi, diantara janji polisi terhadap masyarakat seperti yang pertama Memelihara ketertiban dan menjamin adanya keamanan terhadap setiap warga negara, Memelihara keselamatan orang, benda dan masyarakat, termasuk memberikan perlindungan dan pertolongan. Kedua Memelihara keselamatan negara terhadap ganguan dari dalam. Ketiga Mencegah dan memberantas menjalarnya penyakit-penyakit masyarakat. Keempat Mengusahakan ketaatan warga negara dan masyarakat terhadap peraturan negara. ${ }^{21}$

Selanjutnya undang-undang kepolisian pada pasal 13 memberikan penjelasan mengenai Tugas pokok Kepolisian dalam lingkup Negara kestuan Republik Indonesia yaitu; Memelihara keamanan dan ketertiban masyarakat; menjadi penegakkan hukum; serta Memberikan perlindungan, pengayoman, dan pelayanan kepada masyarakat. ${ }^{22}$

Pelaksanaan tugas pokok kepolisian tersebut kemudian dijabarkan kembali secara terperinci dalam aturan undang-undang yang mengatur tentang Polisi seperti pada pasal 14 pada poin a sampai i, sebagai bagian dari penjabaran pasal 13. Pada pasal tersebut memberikan beberapa poin penting mengenai tugas pokok Kepolisian diantaranya : melakukan pengaturan, penjagaan, dan pengawalan, serta patroli terhadap seluruh aktivitas yang dilakukan oleh masyarakat maupun pemerintah sesuai kebutuhannya, selain itu polisi juga harus mampu menjadi penyelenggara atas berbagai kegiatan untuk menjamin terciptanya keamanan, ketertiban, dan kelancaran berlalu lintas di jalan raya, tugas selanjutnya yaitu polisi harus mampu menjdi pembina bagi masyarakat untuk meningatkan rasa peduli atau partisipasinya terhadap lingkungan, hukum serta kepatuhan terhadap undang-undang yang berlaku di negara Indonesia, serta menjadi sosok yang menjadi pembimbing terciptanya hukum di masyarakat tujuannya agar tercipta ketertiban serta keamanan secara menyeluruh. Menciptakan kondisi tersebut aparat kepolisian diberikan tanggung jawab untuk senantiasa melakukan koordinasi, pengawasan, dan pembinaan teknis terhadap anggota polisi yang memiliki tugas khusus, penyidik pegawai negeri sipil, dan bentuk pengamanan swakarsa. Selain itu aparat kepolisian diberikan wewenang untuk melaksanakan penyelidikan dan penyidikan terhadap segala pelanggaran pidana, selain penyidikan aparat tersebut di berikan kewenangan mengambil peran untuk menyelenggarakan identifikasi, Kedokteran Kepolisian, laboratorium forensik serta psikologi, hal ini dilakukan dalam menciptakan keselamatan jiwa raga, harta benda, masyarakat, dan lingkungan hidup dari

${ }_{20}$ Viswandro dan bayu Saputra Maria Matilda, Mengenal Profesi Penegak Hukum, Buku Rujukan Berkarier Di Bidang Hukum, Edisi Pert (Jakarta Seatan: Pusaka yustisia, 2015). h. 20.

${ }^{21}$ Satjipto Raharjo.

22 Undang -undang Kepolisian Negara Republik Indonesia Nomor 2 Tahun 2002. 
gangguan ketertiban serta bencana termasuk memberikan bantuan dan pertolongan dengan menjunjung tinggi hak asasi manusia. ${ }^{23}$

Tugas pokok polisi dalam pasal 14 tersebut kemudian memberikan wewenag penuh kepada kepolisian yang sesuai yang tertera dalam pasal selanjutnya yaitu pasal 15 ayat 2 , kewenangan itu, di paparkan secara rinci dengan beberapa poin penting seperti, melaksanakan pengawasan terhadap berbagai kegiatan atau keramaian umum di masyarakat, menelenggarakan identifikasi maupun regitrasi kendaraan, memberikan bantuan surat izin mengemudi pada para pengemudi, pengawasan kegitan politik, pengawasan terhdap benda yang berbahaya seperti senjata api, serta bahan yang berpotensi meledak, melakukan pemberian izin operasional terhadap bidang keamanan lainnya selain polisi, memberikan pelatihan kepada kepolisian khusus dan melaksanakan kerja sama dengan polisi pada sektor maupun dengan negara lain, serta melaksakan tugas lainnya yang merupakan peningkatan serta manfaat bagi negara sesuai dengan fungsinya sebagai aparat kepolisian. ${ }^{24}$

Kewengan dari kepolisian tersebut memberikan gambaran akan peran dan fungsi kepolisian di negara kesatuan republik Indonesia ini, hal tersebut akan berjalan dengan baik apabila setiap anggota kepolisian mempu menerapkan dan melaksanakan tugasnya selaku pelayanan dan perlindungan terhadap masyarakat. Maria matilda dalam bukunya mengenal profesi penegak hukum memaparkan bahwa, setiap anggota kepolisian wajib memperhatikan beberapa asas agar seluruh cita-cita dan tujuan kepolisian melalui wewenang yang telah diberikan dapat tercipta dengan baik. Beberapa asas yang perlu menjadi bahan perhatian dari aparat tersebut yaitu, pertama asas legalitas, yaitu asas atau prinsip yang menyatakan bahwa semua tindakan polisi harus sesuai dengan hukum yang berlaku. Artinya, asas atau prinsip legalitas di gunakan untuk tindakan polisi untuk mencapai tujuannya yaitu penegakan hukum. Kedua asas nesesitas yang berarti penggunaan kekuatan dapat dilakukan bila memang diperlukan dan tidak dapat dihadirkan berdasarkan situasi yang dihadapi. Penggunaan asas nesesitas dapat diterapkan dalam beberapa kondisi yang mengharuskan hal tersebut harus dilakukan sesegera mungkin. Dan yang ketiga adalah asas proporsionalita, asas ini memberikan pengertian tentang penggunaan kekuatan harus dilaksanakan secara seimbang antara ancaman yang dihadapi dan tingkat kekuatan atau respon polisi, sehingga tidak menimbulkan kerugian atau korban atau penderita yang berlebihan. ${ }^{25}$

\section{Polisi Santri}

Kepolisian Negara Republik Indonesia merupakan suatu lembaga atau alat kelengkapan negara yang senantiasa memberikan terobosannya, untuk

\footnotetext{
${ }^{23}$ Undang -undang Kepolisian Negara Republik Indonesia Nomor 2 Tahun 2002.

${ }^{24}$ Undang -undang Kepolisian Negara Republik Indonesia Nomor 2 Tahun 2002.

${ }^{25}$ Maria Matilda.
} 
menjamin terciptanya suasana negara yang berdasarkan amanat undang-undang dasar 1945. Polisi dalam menjalankan amanat tersebut, senantiasa berpedoman pada Undang-undang nomor 2 tahun 2002 tentang Kepolisian. Melalui undangundang kepolisian tersebut, polisi menjalankan tugasnya sebagai lembaga yang miliki peran untuk memberikan rasa aman dan ketertiban umum untuk menjamin ketentraman terhadap pelanggaran-pelanggaran hukum yang terjadi di masyarakat. Mengenai pelanggaran hukum polisi yang berperan sbagai penegak hukum, kemudian melakukan usaha hukum terhadap pelanggar hukum, akan tetapi prakteknya konsenkuensi hukum yang dijatuhkan tidak semerta-merta bisa memberikan efek jera kepada pelaku, sehingga di butuhkan salah satu metode penanganan yang tepat. Visi misi kepolisian yang kemudian mengedepankan prinsip melindungi dan mengayomi sehingga di sulawesi selatan khususnya di kota palopo, melalui Polres Palopo membuat salah satu organisasi internal dalam kepolisian yaitu Polisi Santri Polres Palopo. Polisi Santri merupakan suatu wadah perkumpulan beberapa personil Polisi yang telah di bekali dengan pengetahuan tentang agama melalui kegiatan pesantren serta majelis ilmu yang di fasilitasi oleh instansi kepolisian setempat, serta menjadi tempat bagi polisi untuk melakukan pembinaan rohani melalui pendekatan agama.

\section{Tujuan, Fungsi dan Peran Polisi Santri}

Polisi Santri yang beranggotan beberapa personil Polisi ini, dibentuk melalui keputusan rapat serta musyawarah dengan pimpinan Kepolisian Sulawesi selatan dan daerah, diharapkan bahwa pembentukan ini, dapat menjadi bagian dari metode kepolisin untuk memberikan pembinaan kepada masyarakat melaui pendekatan agama Islam, dimana hampir sebagian besar penduduk kota palopo bergama Islam, tujuannya agar baik pernah terjerat kasus hukum ataupun yang tidak pernah bersentuhan dengan kasus hukum untuk menjadi pribadi atau masyarakat yang baik, selain itu, program ini sebagai bagian untuk mejalin kedekatan dan silaturrahmi bagi masyarakat utamanya masyarakat Kota palopo untuk menimalisr terjadinya pelanggaran hukum. Para personil polisi yang tergabung adalam polisi santri tersebut tidak hanya melakukan program kerja terhadap masyarakat, akan tetapi menjadi wadah bagi oknum polisi yang melakukan pelanggaran maupun bagi anggota kepolisian yang beragama Islam yang ingin menambah wawasan keIslaman.

Berdirinya polisi santri Polres Palopo ini sejalan dengan Undang -undang No. 2 tahun 2002 tentang Kepolisian melalui visi misi kepolisian yang mengutaman perlindungan dan pengayoman terhadap masyarakat, hal ini sejalan dengan pendapat Jeremy Bentham bahwa polisi secara umum adalah sistem pencegahan, baik pencegahan kejahatan atau bencana. ${ }^{26}$ Bahkan dalam kesimpulan dari jeremy, pada poin ke empat bahwa Polisi untuk amal. Hal ini

${ }_{26}$ Viswandro dan bayu Saputra Maria Matilda, Mengenal Profesi Penegak Hukum, Buku Rujukan Berkarier Di Bidang Hukum, Edisi Pert (Jakarta Seatan: Pusaka yustisia, 2015). H. 8 
memberikan gambaran bahwa menjadi polisi merupakan salah satu bagian dari pengamalan agama serta menjadi ladang kebaikan untuk pribadi dan lingkungan sekitar.

Adapun yang menjadi program kerja Polisi Santri Khususnyan yang terdapat di Kota Palopo, yaitu melakukan Safari da'wah dari masjid kemasjid di tiap daerah yang dalam lingkup kerja Polres Palopo, dengan mengunjungi tiap rumah melalui program andalan Polisi yaitu one day one friends dan program dor to dor sistem. Selain itu progaram rutin yang di laksanakan yaitu melakukan safari jumat dan safari subuh, dimana personil Polisi santri menjadi pelaksana pada seluruh rangkaian ibadah jumat mulai dari muazin, khatib dan imam shalat, dan pada safari subuh polisi santri mengisi ceramah subuh dan terkadang membantu panitia masjid untuk menjadi petugas azan, iqomah serta imam shalat subuh, bahkan setiap selesai melaksakan ibadah sholat jumat atau subuh personil Polisi Santri kemudian mengajak masyarakat bermusyawarah.

Tujuan dari program kerja yang di laksanakan oleh pihak Kepolisian Resor Kota Palopo, melalui Polisi santri Polres palopo yaitu sebagai langkah awal pendekatan kepada masyarakat untuk melakukan pembinaan dan pendampingan hukum dengan cara menjadi teladan melalui pendekatan agama. Hal yang di lakukan oleh pihak personil Polisi Santri yaitu dengan menyemarakan dan mengajak lapisan masyarakat muslim untuk senantiasa memakmurkan masjid melalui shalat berjamaah, majelis ilmu seperti ceramah dan belajar mengajar alquran. Tujuan tersebut berfungsi untuk menjadikan masyarakat Kota Palopo menjadi Pribadi yang unggul dan jauh dari kasus hukum melalui metode perbaikan pengamalan agama dalam kehidupan sehariharinya. Hal tersebut mencerminkan peran Polisi sebagai Pengayom dan pelayan bagi masyakat.

\section{E. KESIMPULAN}

Lembaga kepolisian adalah suatu lembaga yang memiliki peran sebagai lembaga yang diharapkan mampu memberikan keamanan dan ketentraman masyarakat dengan menjadi pelindung pengayom dan penegak hukum. Tergambar bahwa untuk mewujudkan keamanan dan ketentraman bagi masyarkat, maka kepolisian harus menjadi pelindung serta pengayom sebelum menjadi penegak hukum, sehingga kepolisian Resor kota Palopo membentuk satu lembaga internal yaitu Polisi Santri Polres Palopo yang berfungsi malakukan kontrol sebagai bagian dari perlindungan dan pengayoman kepada masyarakat muslim yang berada di Kota Palopo, melalui program pendekatan agama khususnya agama Islam. Fungsinya agar setiap masyarakat mampu menjadi pribadi yang senantiasa mengamalkan nilai-nilai Islam dalam kehidupannya, dengan taat melaksakan perintah agama sebagai benteng pencegahan terhadap 
hal yang akan menjadi perusak tatanan keamanan dan ketentraman masyarakat dan negara.

\section{DAFTAR PUSTAKA}

Black, Henry Campbell, 'Black' S Law Dictionary', West Publisihing Co, 1999, 1956

Bruno, Latour, 'ANALISIS YURIDIS FORUM KEMITRAAN POLISI DAN MASYARAKAT DALAM PENYELESAIAN MASALAH MELALUI MUSYAWARAH BERDASARKAN SKEP KAPOLRI NO. : SKEP/737/X/2005 TENTANG KEBIJAKAN DAN STRATEGI KEPOLISIAN', Journal of Chemical $\begin{array}{llll}\text { Information } & \text { and } & \text { Modeling, } & \end{array}$ $<$ https://doi.org/10.1017/CBO9781107415324.004>

Burhan Buangin, Penelitian Kualitatif, ed. by Katalog dalam Terbitan, Pertama Ce (Jakarta: Kencana Pranada Media Group, 2008)

Kelik Pramudya dan Ananto Widiatmoko, Pedoman Etika Profesi Aparat Hukum (Yogyakarta, 2010)

Maria Matilda, Viswandro dan bayu Saputra, Mengenal Profesi Penegak Hukum, Buku Rujukan Berkarier Di Bidang Hukum, ed. by samuel B T Simongkir, Edisi Pert (Jakarta Seatan: Pusaka yustisia, 2015)

Redaksi Sinar Grafika, Undang Undang Nomor 20 Tahun 1982 Tentang KetentuanKetentuan Pokok Pertahanan Keamanan Negara Republik Indonesia, ed. by PT Karya Unipress, Cetakan Ke (Jakarta: Sinar Grafika, 1995)

Satjipto Raharjo, Penegakan Hukum Suatu Tinjaun Sosiologis, ed. by genta, Edisi 1 (Yogyakarta: genta publising, 2011)

Soerjono Soekanto, Pengantar Penelitian Hukum, Cet. 3 (Jakarta: PT Universitas Indonesia, 2010)

Tim Redaksi Kamus Bahasa Indonesia, Kamus Bahasa Indonesia, Kedua (Jakarta Pusat, 2008)

Umi Salamah, Suratman, Munir, Pendidikan Kewarganegaraan Untuk Perguruan Tinggi, ed. by Anggota IKAPI, Pertama (Malang: Madani, 2017)

Undang -undang Kepolisian Negara Republik Indonesia Nomor 2 Tahun 2002, Undang Undang Kepolisian Negara Republik Indonesia, ed. by Sinar grafika Offset, Cetakan ke (Jakarta: Sinar Grafika, 2009)

Wahid, 'Peranan Polri Dalam Penegak Keadilan Masyarakat Dalam Perspektif', 8.1 (2015), 1-13 